\title{
Relational craft and Australian fashionability in the 1970s-80s: Friends, pathways, ideas and aesthetics
}

\author{
Sally Gray
}

\begin{abstract}
Five Australian interdisciplinary practitioners, working across fashion, craft, art and design, in Sydney and Melbourne in the 1970s-80s, shared friendships, aesthetic ideas and public presentation of their work. The ways they chose to make and disseminate their work were influenced by historically reclaimed visual conventions and craft discourses of the time, along with related circumstances of curatorship, collecting and dealing. All of this was foregrounded by contemporary interest in issues of identity and subjectivity as part of a postmodern re-orienting of 'what was what' in visual culture. The essay examines the multi-dimensional 'relationality' of these interconnections.
\end{abstract}

In this paper I trace the work and influences of a group of young Australians whose creative practice in the 1970s and 1980s encompassed fashion, craft, art and design. They shared personal friendships and visual concerns but, importantly, the idea of relationality between people and creative ideas is integral to their work. Peter Tully, the Melbourne-born, Sydney-active, artist and craftsperson (1947-92) often remarked on the importance to his work of a network of creative friends and influences. With his trademark self-mocking irony, he named William Yang 'the court photographer', referring to Yang's photographic documentation of Tully's parties, shows and appearances, and those of fashionable Sydney generally (Yang, 1984). Tully was also in the habit of referring to his extended creative network as 'the family'. Like others discussed here, Tully had 'relationality' at the heart of his life and work in the seventies and eighties, well in advance of Nicolas Bourriaud's invitation for us to think of art's 'theoretical horizon' as being the 'realm of human interactions' and 'social context' (Bourriaud, 2002, p. 14).

The key relational players considered here are Peter Tully, David McDiarmid (1952-95), Linda Jackson (b. 1950), Jenny Kee (b. 1947) and Clarence Chai (b. 1946). Although they also collaborated with many others, this group shares a range of relational concerns which are the subject of this essay.

A fascinating confluence in Australian art and design history occurred when this group, and a wider circle of friends, met and interacted visually, socially and creatively. A set of visual and cultural ideas came together, incubating a hip, postcolonial Australian fashionability, from the early 1970s. Their work, collectively and individually, involved a language of playful colour and contrasts; an interest in the decorative, handcrafted, allegorical and historicist, and an engagement with questions of subjectivity and place. They collectively enjoyed a postmodern 
visual sensibility and a refusal of the received common sense of good taste; their contribution to fashion was, to quote one commentator on Clarence Chai's work, 'definitely not for the shy and retiring' (Barden, 1981, p. 15).

'Relationality' in this episode can be thought of in a number of ways. Firstly, the perception by this group of artists and designers of the importance, to their creative practice, of significant personal relationships. They were not a 'movement', but a study of their work and interconnected lives reveals something of a shared creative vision. The second relationality concerns institutional collecting trends, and the curators who exhibited and interpreted their work. The third notion of relationality that I propose refers to a set of ideas, influential on their work and current at the time. These include an intellectual and material inter-disciplinarity which melds craft, art and fashion; an impulse to engage with eclectic visual ideas from a range of global sources, and an interest in proposing versions of identity and cultural location; Tully's comments above about 'family' and 'court' contain the camp 'attitude' which lays claim to a self-invented group identity not reliant on externally defined concepts of what is fabulous and what is not.

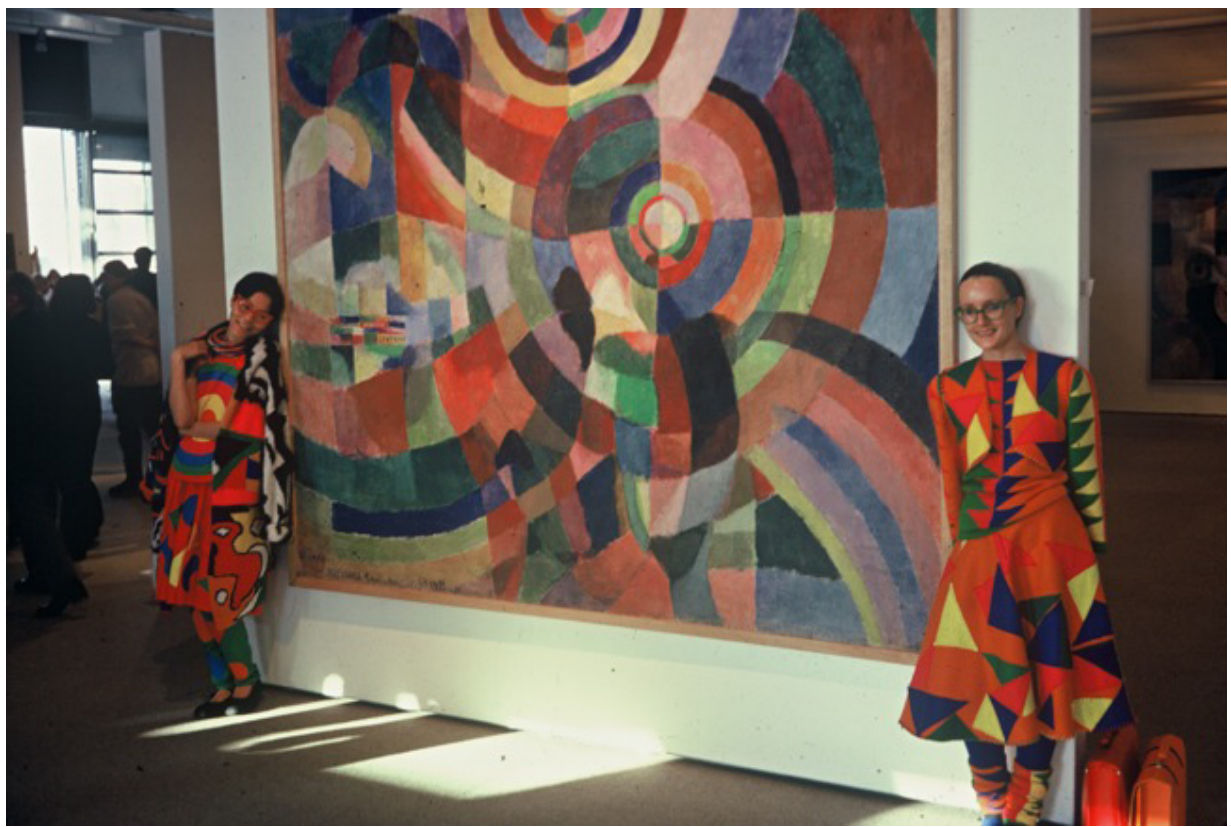

Figure 1. Jenny Kee (left) and Linda Jackson (right) in front of Sonia Delaunay's Prisme Electrique (1914), Pompidou Centre, Paris, October 1977.

Source: Fran Moore.

The photograph (Figure 1) was taken in Paris by Fran Moore in October 1977. Jackson on the right is wearing her Linda Jackson-designed and -made, patchwork felt skirt and waistcoat titled Delaunay (1977), now in the collection of the Powerhouse Museum. These are worn with a hand-knit jumper she had made from a 1940s geometric pattern, using her own colour scheme in five- 
ply wool (Jackson, 2009). Kee (on the left) is wearing a Linda Jackson Chinese poplin appliqué top and skirt (1977), also in a Sonia Delaunay-inspired design, and a hand-knit cardigan designed by Kee and knitted by Jan Ayres, Kee's principal knitter. Kee also wears a Masai plastic tubing necklace by Tully, similar to those shown in Tully's 1976 and 1977 exhibitions in Melbourne and Sydney and in subsequent exhibitions under his 'Urban Tribalwear' rubric. The photograph was taken when Jackson, Kee and Moore (Jackson's then partner) were on their 'suitcase' or 'trunk' show tour to Milan, Paris and New York in late 1977, showing the work of Jackson and Kee under the Flamingo Park label. The collection was a hit with the invited guests who saw it and was taken up by Anna Piaggi of Italian Vogue (Vogue Italia, December 1977).

The image is emblematic of the designers' shared aesthetic enthusiasms, in this case for the visual legacy of modernist artist and designer Delaunay. This enthusiasm was shared by the group of friends and creative collaborators who are the subject of this essay. They met in Melbourne and Sydney in their late teens or early 20 s, before they went on to have the creative careers which, between them, covered the realms of art, design, fashion, craft and community cultural development. They all at one time or another lived together, worked together or showed their work with one or more of the group. They collaborated on parties, outfits, collections, exhibitions and fashion parades.

Jackson and Kee, have been fairly widely written about (McPhee, 1985; Jackson, 1987; Maynard, 1999, 2001; Gray, 1999, 2010, 2011; Jocic, 2012; Kee, 2006; Leong and Somerville, 2010) and the others, most notably Chai, less so. The inter-connected ideas, people and creative output in this group has not, however, previously been discussed. They formed a unique relational network with a unique set of visual histories and influences. We are only just beginning to come to terms with the cultural complexity of what was happening in studio-based Australian fashion in this period (Whitfield, 2010), particularly in Sydney. Questions of who was moving where, who knew whom, what people were thinking and making and how they were doing it, remain to be grappled with. I am interested in tracing the conceptualisation and material production of the work of these people beyond its graphic representation in magazines and photographs.

\section{Studio-based hand-crafted fashion}

My selected group of five were all small-scale, studio-based practitioners who at the time had no particular ambition to become part of the mainstream Australian fashion industry as such - they weren't looking for mass or factory production, large staffs or complex business arrangements. They didn't see themselves in competition with the big names of the established rag trade. As contemporary fashion writer and curator Jane de Teliga put it 'they worked like artists' (de Teliga, 2011). Moreover, they themselves saw their practice in these terms - they were in the process of making fashionable, creative and artistic 
lives, rather than business-based careers. Fashion curator, now academic, Robyn Healy sees this studio-based fashion as in some ways 'a uniquely Australian thing' (2010). As she sees it, this was a particularly Australian kind of 'bespoke or crafted practice which grew up alongside the more commercial, factory-produced Australian fashion scene' (2010). After nearly 10 years in the fashion world, Chai stated in an interview in 1983: 'I don't want to be like the more established designers ... I still want to be involved in innovative fashion' (Barden, 1983). Chai now says he never saw himself as 'becoming big', on the contrary, he thinks:

It was more about friendship instead of a big corporation - everything [was] interconnected rather than people coming in from the outside. I always wanted to keep it under my control and be a bit more creative. Once you get bigger you have to water down your designs. (2011)

'Radical', 'avant garde', 'innovative' were terms commonly used by the fashion press at the time to describe the work of this group. The term 'art clothes' was also used in art, design and craft discourse. As Grace Cochrane put it, 'Many designers set up small businesses ... designing and making art-clothing and accessories' (1989, n.p.).

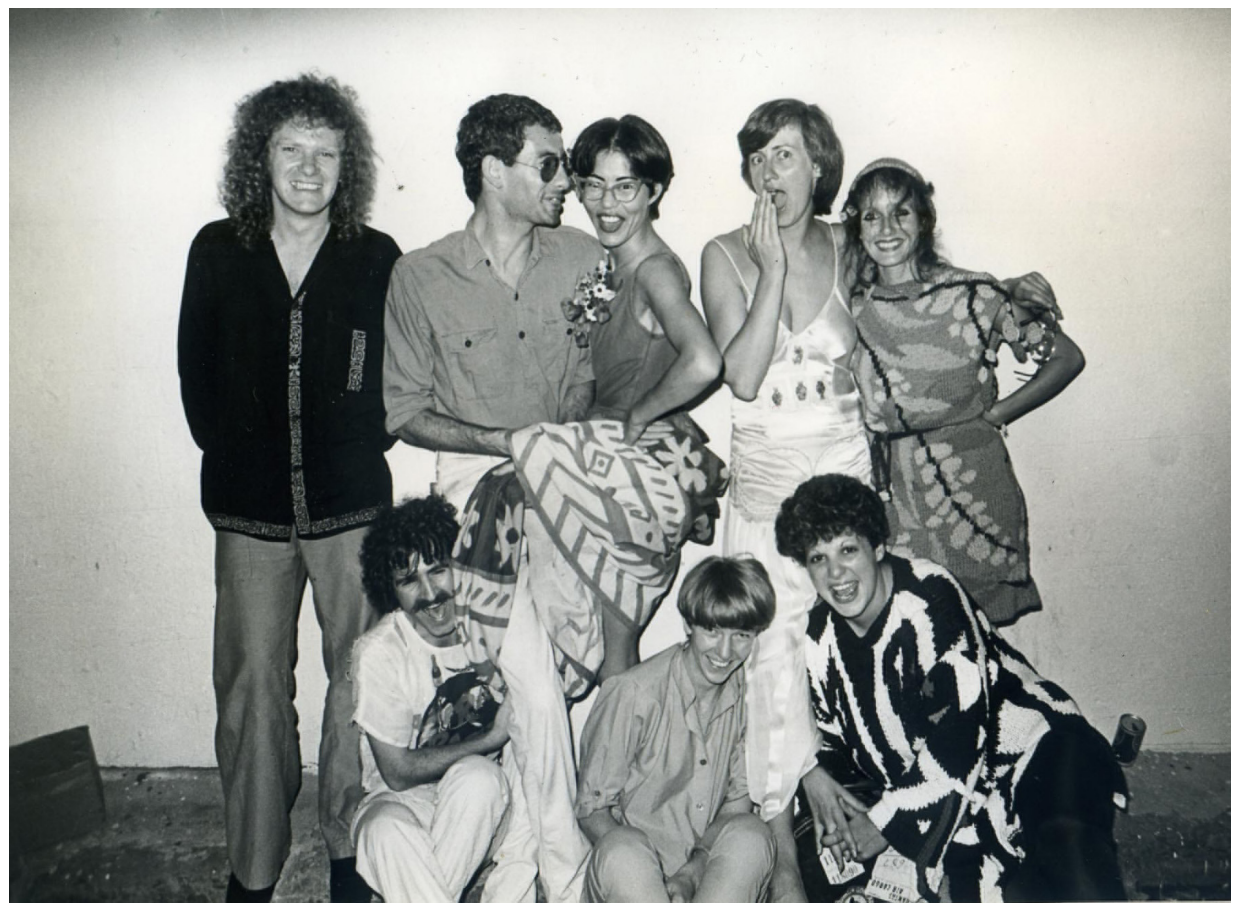

Figure 2. Peter Tully (lower left), Jenny Kee (centre top), Linda Jackson (top right), David McDiarmid (to left of Kee) and friends, photographed at the opening of McDiarmid and Tully's joint exhibitions, Hogarth Galleries, Sydney, 1977. 


\section{Significant others}

All of this group, except for Kee, had their initial training and creative roots in Melbourne. All chose Sydney as the site to fully develop their careers, most from the mid 1970s, Chai from the mid 1980s. Jackson trained in fashion at Emily McPherson College in Melbourne, in 1966-67, and studied photography at Prahran Technical College in 1968. She met Tully and Chai when one day a stranger (who turned out to be Jenny Bateson, a friend of theirs) called out to her on Cardigan Street, Carlton: 'Hey, you look great, come up and meet my friends'. Linda accompanied her to 445 Cardigan Street, where she found housemates Clarence and Peter making costumes for the 1968 annual Melbourne Arts Ball. Jackson would work with Chai as a collaborator and seamstress at his Paraphernalia vintage clothing store in Melbourne's Metropole Arcade while in the process of developing her 'Linda Jackson' design label.

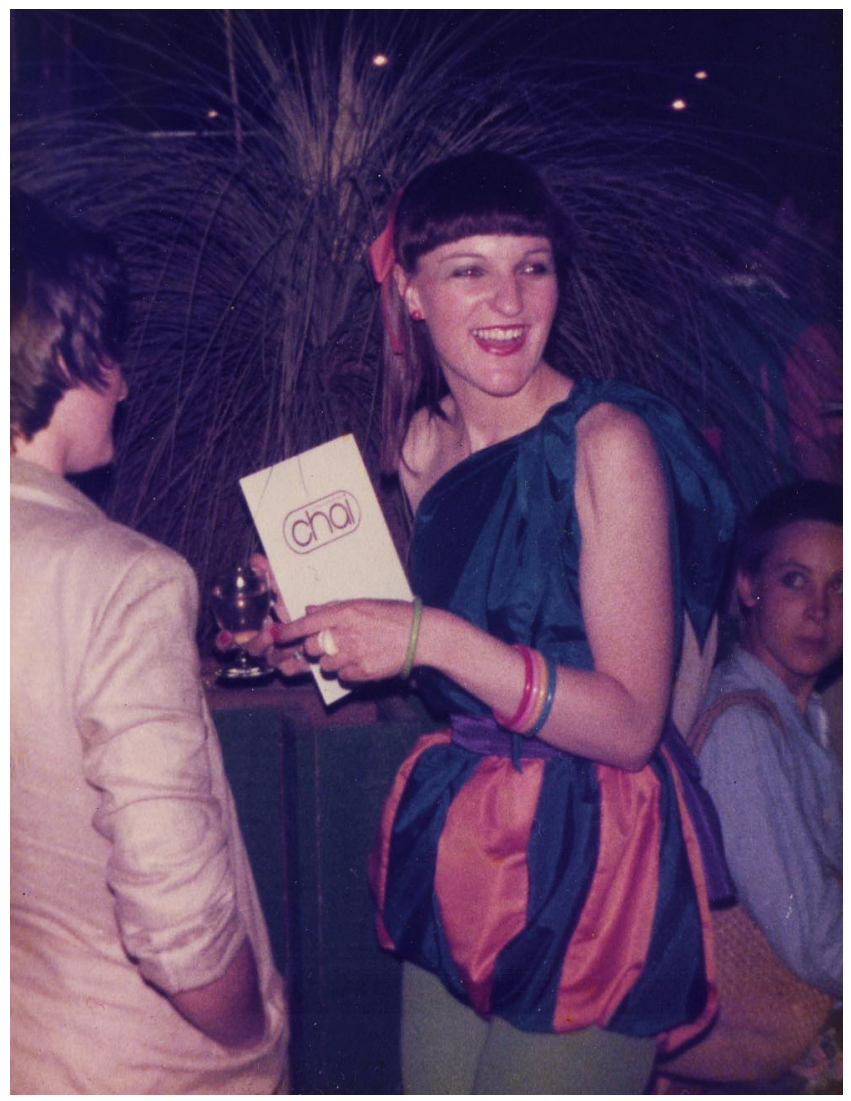

Figure 3. Margot Gray, 'Chai' Parade, Universal Workshop, Melbourne, 1978.

Source: Clarence Chai. 
Chai's independent fashion career began in 1974 when he opened his store Chai Clothing and Accessories, at 5 Crossley Street, Melbourne. He had previously been a vintage clothing and textile dealer under the Paraphernalia name with his former partner, Paul Craft. An extended period in London in 1973, where he saw the collection of Australian-born, vintage clothing dealer Vern Lambert, had convinced him that he could translate his enthusiasm for vintage textiles and his training in graphic design at RMIT Melbourne into a fashion practice. $\mathrm{He}$ had worked as a graphic designer for Garry Emery and Brian Sadgrove in Melbourne, and had always had a strongly graphic visual sensibility. His feeling for clothing had been nurtured in childhood when he loved 'picking up the pins' in his neighbours' sewing workroom at 56 Orchard Road, Singapore. Chai sold Linda Jackson designs along with those of Jenny Bannister and others who were making edgy, radical clothing by hand. In November 1978 Chai launched his second shop at 105 Collins Street, with a parade at The Universal Workshop in Fitzroy, showing Jackson, Kee, Bannister and his own Chai label. According to a contemporary observer, Chai's vivid shop-window display was 'a standing affront to the sensibilities of the sedate society matrons who promenaded down this high rent strip of retail property' (Barden, 1981, p. 15).

Tully trained as a jeweller at Victoria State College and later at Randwick Technical College, Sydney, after years of world travel in his early 20 s, working as a waiter and English-teacher to pay his way. He and Chai had met as teenage waiters, in the coastal Victorian town of Lorne, in the summer of 1964/65. They later lived together in shared houses in Carlton, where making outfits, dressing up and partying were central. In 1969 Linda and Peter, along with Linda's then partner Fran Moore, travelled together to Papua New Guinea where they lived for a year in Madang and Lae soaking up the tribal aesthetics that would impact on both Tully's and Jackson's work. After this, they travelled, separately and together, throughout South East Asia, Africa and Europe. Jackson worked as a seamstress, honing her skills, including working for six months in Paris with fashion label Mia and Vicki. Tully was continually collecting transcultural visual material - feathers, tribal jewellery, handcrafted textiles - and ideas for his later jewellery design, from sources as diverse as New Guinea, Ethiopia, Singapore and Amsterdam.

McDiarmid studied film, art history and illustration at Swinburne College of Technology in Melbourne in 1969-70 before becoming a gay activist artist. Travelling back and forth between Sydney and Melbourne in the early 1970s, he helped found Sydney Gay Liberation in 1972 and formed a radical, gay male, politically focused, household in Melbourne in the same year, simultaneously developing the material for what would become his political art. He met Tully in 1973 and, briefly lovers, they shared a house in Elgin Street Carlton. In 1974-75 they travelled together in South East Asia before separately settling in Sydney in 1975. It was the fact that Jackson and Moore had already moved to Sydney, after Linda met Kee in 1973, that convinced Tully and McDiarmid that they too would make the move north on their return from Asia. McDiarmid was soon handpainting fabrics for Jackson's dresses and Tully was making jewellery for 
Flamingo Park. For the next 18 years, until Tully's death in Paris in 1992, Tully and McDiarmid shared ideas, projects, politics, inspiration, friends, exhibitions and, at times, both studio and living space in Sydney and New York.

Kee studied dress design at East Sydney Technical College in 1963-64 before her departure for London in November 1965. In London she worked at Biba, and later learned fashion history under the informal tutelage of Lambert when she worked for Emmerton and Lambert selling vintage textiles and couture at Chelsea Antique Market between 1967 and 1972. Kee met Jackson in June 1973 at Craft's Paraphernalia stand at the Antique Winter Fair at Bonython Gallery, in Sydney. Craft, who had previously run Paraphernalia in partnership with Chai, was showing a collection of Jackson's one-off, hand-crafted garments along with his selection of art nouveau and art deco collectibles. Kee says she was:

... stopped in [her] tracks by a row of Hawaiian and assorted fifties print gored skirts with bra tops, little flared shorts and cute shirts. Each outfit had a different pattern: roses, letters of the alphabet, abstract shapes. I knew this girl and I were on the same wave-length. (2006, p. 135)

Kee had returned to Sydney in December 1972 and was about to open her soon-to-be-famous 'frock shop' Flamingo Park in Sydney's Strand Arcade, selling innovative handmade and vintage clothing. It was the instant visual and creative rapport between the two women, along with a job offer in Sydney for Moore, which convinced she and Jackson that they should immediately resettle in Sydney (Jackson, 2011; Moore, 2011). Between 1973 and 1982, when she established her own Bush Couture label, Jackson's creative output would help create the signature aesthetic, and glamorous cachet, of Flamingo Park.

\section{Establishing a youthful, hand-crafted aesthetic}

On 10 December 1974, the first Flamingo Park parade, 'Flamingo Follies', was held at the Hingara restaurant in Chinatown, Sydney. It opened with Jackson's 'Opera House' outfit in celebration of her adopted city and Joern Utzon's newly opened Sydney Opera House. With white 'sails' appliquéd onto blue linen, the two-piece outfit had the one-off, 'artful', quotational sensibility which would mark Jackson's and Kee's output in the shared Flamingo Park years. In this first show, Kee, Jackson and their collaborators had brought a set of ideas to fruition that found a receptive moment in mid-1970s Sydney. The most significant of these was the capacity to view Australia from the outside and to create a sense of Australian fashionability which did not rely on familiar local frames of reference. Counterintuitively, this involved the inauguration of the Australiana for which the two designers are well known. Kee had already developed the prototypes for her Australiana knits by 1974; Tully and McDiarmid were among the first to wear them (Kee, 2006, p. 156). The first Flamingo Follies show was colourful, irreverent, hip and graphically compelling. Young, non-professional models moved with youthful verve to reggae music, creating a visual and corporeal language as yet unseen on Australian catwalks. 


\section{Dealing in the decorative}

The embracing of expressive, experimental and decorative personal adornment, as a reaction to high modernism in architecture, fashion and art was, as we now see it, part of the 'post modern turn' (Best and Kellner, 1997). A search for a sense of style to delight and entertain, playful quotation from familiar and historical visual tropes, and optical stimulation from patterns, colours and contrasts, previously thought of as vulgar or tasteless, formed part of this. Commercial dealing in post-belle époque decorative arts expanded from the early 1970s when this group was setting its aesthetic agendas. Firms like Butler and Wilson, established in 1969 as an antique jewellery stand at Antiquarius, Kings Road, London, along with the major auction houses in London, New York and Paris, had helped create a new decorative and historicist fashionability through their dealing in jewellery and objects d'art from the fin de siècle to the mid-twentieth century. In 1970, Craft and Chai, then in their early 20s, established Paraphernalia, first at an antique market in Bourke Street and then, in the Metropole Arcade, Melbourne. Paraphernalia quickly became one of the leading Australian dealers in museum-quality objects dating from the 1890s to the 1940s. Paraphernalia also sold, in a second, adjoining shop in the arcade, clothing and textiles of the same period. This was Chai's special interest, and would lead to establishment of his Chai fashion label and shop in 1974.

It was also in the 1970s that interest in collecting vintage couture and textiles took off. Kee recounts how Lambert 'had a history of global fashion hanging in his shop and filed away in his brain' (Kee, 2006, p. 76). In 1970-71 Lambert had worked with Cecil Beaton on the important exhibition, 'Fashion an Anthology' at the Victoria and Albert Museum, London (Beaton, 1971, p. 12-14). Lambert also sold inventive contemporary dress, made from vintage fabrics, at his shops in the Chelsea and Kensington antique markets. Chai remembers how inspired he was by Lambert's textile collecting acuity when he visited the Chelsea Antique Market in 1973, recalling that Lambert 'was doing a lot of patchwork stuff made out of old fabrics; skirts and dresses from scarves; bomber jackets from old tapestry and curtains' (2011). Chai had similar fabrics, which he had been collecting since 1970 for Paraphernalia. In 1974, on his return to Melbourne, he opened his separate fashion business, Chai, to sell his line of garments made from vintage fabrics.

Through the 1960s and early 1970s, Sotheby's London held a number of important auctions of Ballets Russes costumes and sets (Spencer, 1973, p. 245). Almost a third of the funds raised from the March 1973 Sotheby's sale came from bids placed on behalf of the not-yet-opened Australian National Gallery (ANG, later National Gallery of Australia) (Pritchard, 2010, p. 167). Lambert acquired costumes and backdrops from the Ballets Russes auction sales, some of which he showed Chai on his visit to London in 1973, and examples of which Lambert gave to Jackson and Kee. 


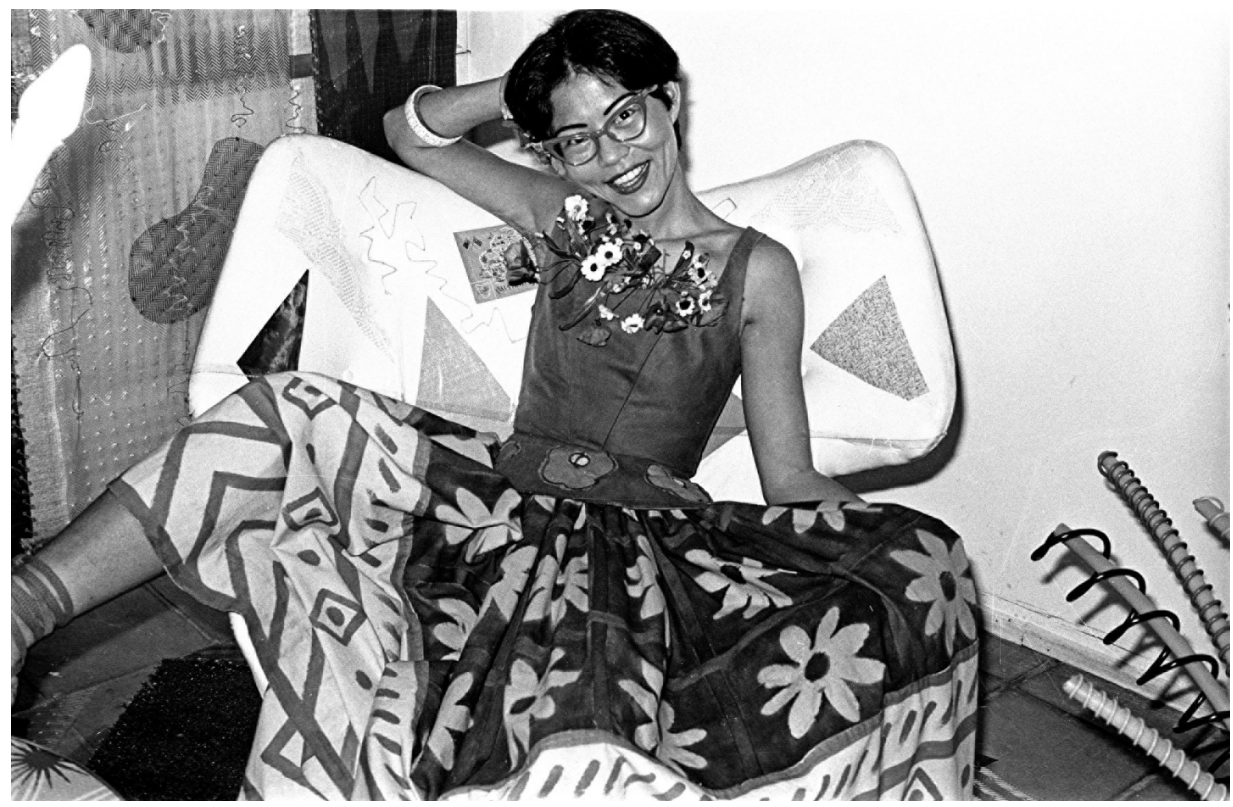

Figure 4. Jenny Kee wearing Natalia Goncharova-designed Ballets Russes costume from le Coq d'Or, photographed in David McDiarmid's Australian Dream Lounge, Hogarth Galleries, Sydney, 1977.

Source: William Yang.

The photograph of Kee, above, wearing an original Ballets Russes costume, was taken by Yang at Hogarth Galleries Sydney in December 1977, at the joint opening of Tully's 'Living Plastics' exhibition and McDiarmid's Australian Dream Lounge. McDiarmid had just returned from his first extended period in the United States and the dream lounge was his insider/outsider comment on postwar Australiana. Kee is wearing a Natalia Goncharova-designed 'peasant maid's' costume from le Coq d'Or, (1914), purchased at auction by Lambert and given to Kee as a gift. She is photographed in McDiarmid's Australian Dream Lounge.

The dynamism and colour of Ballets Russes costume design was incorporated into the aesthetic mix of this group of Australian practitioners. McDiarmid did a range of handpainted designs on white wool-crepe for Jackson outfits for the 1977 Flamingo Follies parade. Based on Nicholas Roerich's designs for the original production of le Sacre du Printemps (1913), this work is typical of a decorative, historicist aesthetic adopted by McDiarmid for his fabric painting work and demonstrates both his attention to craft technique and the group's eclectic range of visual sources. 


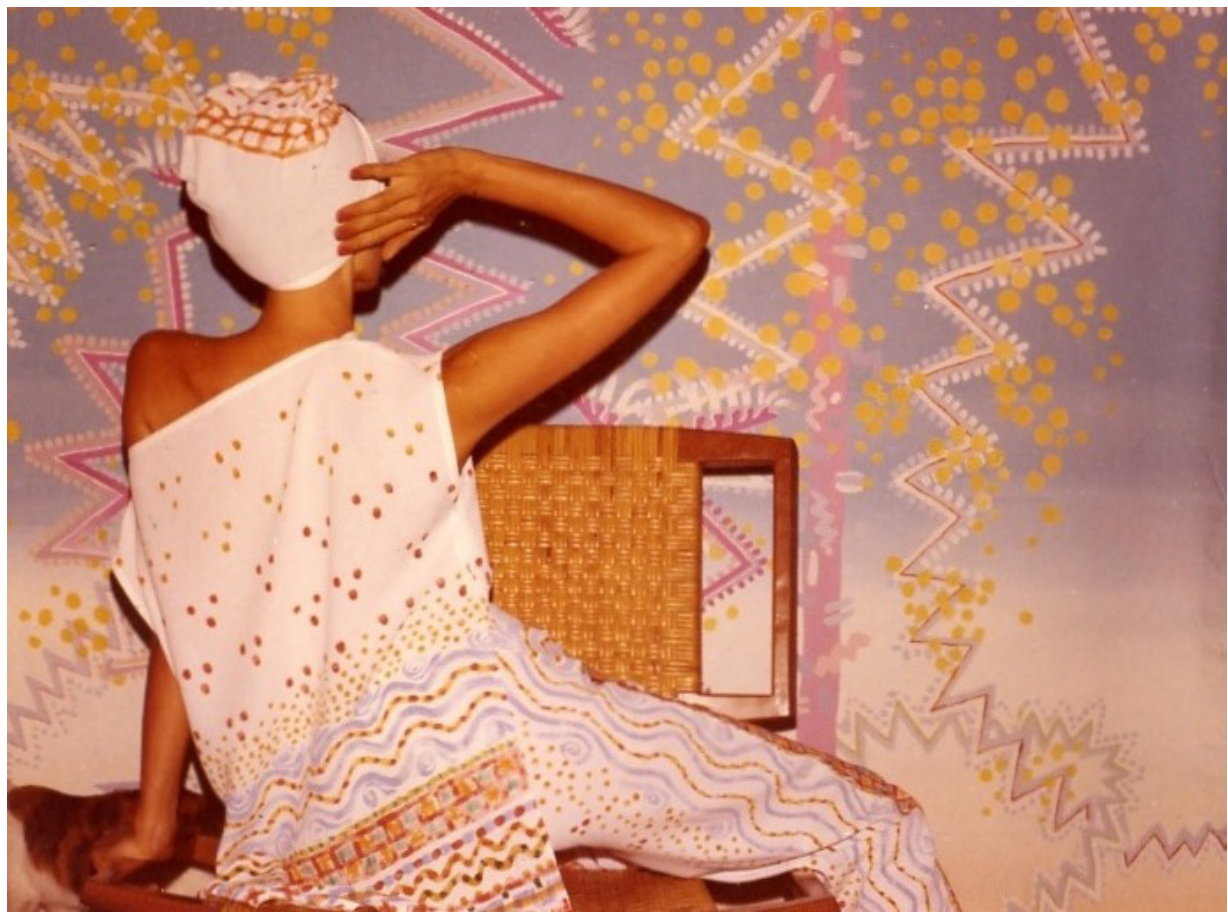

Figure 5. Linda Jackson wearing her white wool-crepe outfit with handpainted design by David McDiarmid, based on Nicholas Roerich's designs for the Ballets Russes production of le Sacre du Printemps (1913), Jackson is photographed in front of McDiarmid's Wattle and Scribbly Bark mural at 155 Little Oxford St, Darlinghurst, Sydney, 1977.

Source: David McDiarmid.

\section{Fashionable identity and subjectivity}

As will be evident, this group was well travelled, with wide exposure to global visual culture, before starting their creative careers. They developed the capacity to view Australia from the outside and to collect and interpret visual and cultural ideas wherever they found them - whether that was Addis Ababa, New York, Penang or Paris - and to share their visual enthusiasms and influences. Kee, Jackson and Tully are all well known for their adoption of Australiana motifs in their work - flora and fauna, visual quotations from tourist kitsch. McDiarmid is less well known for this but, as mentioned, his Australian Dream Lounge installation at Hogarth Galleries in 1977 celebrated, with an ironic inflection, Australian postwar suburban optimism.

As mentioned above, they all shared an enthusiasm for Sonia Delaunay whose work they had simultaneously discovered through the books (Damase, 1971, 1972) on her work and career, published in the last decade of Delaunay's life she died in 1979. Visits to art museums in Europe and North America also inspired 
an interest in Delaunay's art-as-life inter-disciplinarity, and her collaborative projects, which provided a model for this group who saw similarities with what they were doing.

Always interested in relationships between art and fashion, Jackson had been influenced by the Fauves and the Ballets Russes and Jackson and Kee were both interested in Delaunay's drawings and her writings on theories of colour. Jackson had studied colour theory, in the 1960s, in books she had found in the Theosophical Bookshop in Melbourne. In those days Jackson recalls: 'There were not many books like that around. But I ordered every book on Delaunay the minute they were published - we were mad about her' (2009). Early in 1977 Kee asked Jackson to make her a felt appliqué outfit based on a Delaunay painting using discs of felt. 'It was through doing this' Jackson says:

... that I learned - by doing the cut-outs - how Delaunay had done what she did. It was through that, that I learned that language. Jenny and I were obsessed by what we called 'colour and shape'; when 'Rhythm and Colour' [Damase, 1972] came to our attention it was revelation. (2009)

Delaunay herself had famously discovered her own modernist method when she made a patchwork coverlet for her son Charles in 1911. This intimate crafted work is credited with being her introduction to abstraction.

Tully shared this Delaunay enthusiasm and made jewellery such as the necklace of geometric discs entitled, Delaunay Delight (now in a Melbourne private collection), and a plastic and vinyl waistcoat of the same name with the same geometric discs (both 1977). The latter, in the collection of the National Gallery of Victoria (NGV), Melbourne, was shown in the NGV's 'Manstyle' exhibition (March-December 2011).

McDiarmid's enthusiasm for Delaunay became part of a joint project with Jackson as garments were prepared for the 1978 Flamingo Follies parade. Jackson recalls that:

David had been painting the delicate gum-leaves and the Russian Ballet designs in 1977 but when [we saw more of Delaunay's work], I suggested he use a bigger, wider brush and he produced [that work] for the 1978 Queen Street [Woollahra, Sydney] Flamingo Park parade. (2009)

Chai was simultaneously following his own enthusiasm for Delaunay in Melbourne, developing clothing based on cut-outs and geometric discs after he also acquired the Damase book in the early seventies. He saw Delaunay's work at the Museum of Modern Art, New York, in 1979 and had acquired one of the Delaunay ceramic multiples made in the 1970s (Chai, 2011). Enthusiasm for Delaunay was just one of several, relationally interconnected visual themes and tropes, translated into a variety of crafted techniques, by this group as, separately and together, they mined global culture for inspiration. 


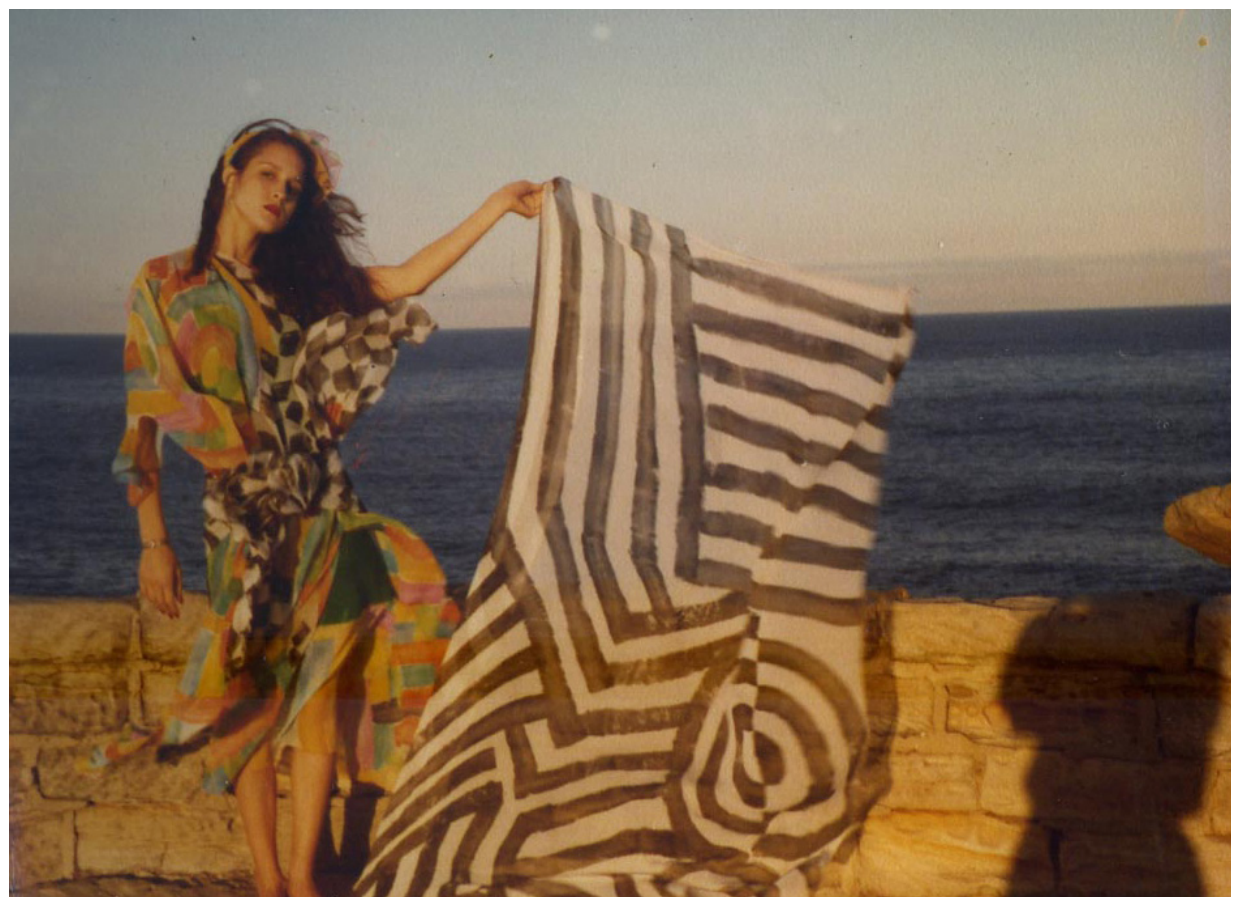

Figure 6. David McDiarmid, hand-painted Sonia Delaunay-inspired design on silk chiffon for Linda Jackson outfit for Flamingo Park,1978.

Source: Linda Jackson.

\section{Intercultural relationality}

Flamingo Follies and Chai parades showcased an Asian-inflected transcultural aesthetic and mood which saw Australia from the outside and embraced global visual aesthetics. Singapore-born Chai chose to emphasise an Asian aesthetic in his work (Chai, 2010), and a contemporary observer noted that Chai's shop was sometimes confused with a Chinese tea-shop when it opened close to Melbourne's Chinatown in 1974 (Mehra, 1984). The Hingara restaurant, site of the first Flamingo Follies, was Kee's Chinese father's preferred Chinatown restaurant. With its postwar laminex walls in lemon, rose and pale green, it was the perfect setting for this show and its audience, receptive as both were to a postmodern re-evaluation of what had been classed by modernist orthodoxy as kitsch. Yum cha was served (as it was also at Chai's 1978 parade) and Jackson's collection of Chinese opera costumes, acquired through Chinese friends in Kuala Lumpur in 1971, were integrated into the parade as more than mere 'exotic' additions. The event was small, with guests seated around an arrangement of restaurant tables, which doubled as the catwalk. The feeling was that something new, dynamic and special was happening. 


\section{Framing fashion within craft in the 1970s}

The handmade and studio-based focus of this group was against a background of contemporary interest in the retrieval of craft and decorative arts within Australian (and international) art and design discourse. In the 10 years to 1974, the craft movement 'gained a momentum undreamed of ten years before, and a wave of activity was generated throughout the country' (Australia Council for the Arts, 1975). The ideological framing of craft was broad, encompassing conservative craft traditions as well as 'alternative lifestyles, survival, women's lib, the spread of the arts, and community schooling' (Australia Council for the Arts, 1975). The political and ideological currency of craft gave an additional context, outside of the fashion industry, for this group's critical reception.

This was particularly true for Tully's work. The inauguration of the Crafts Board of the Australia Council in 1973 provided critical acceptance, funds and exhibition projects for Tully's interdisciplinary art/fashion/craft practice. Tully had by this time established a strong independent aesthetic for his handmade jewellery pieces.

A bricolage of found and self-crafted objects, often using plastics, Tully's jewellery re-evaluated and re-positioned suburban postwar kitsch. He employed a self-designated 'tribal' aesthetic, which he pulled together from his significant exposure to the world's cultures, including from June 1979, urban New York. The Crafts Council of Australia hosted Tully's 1980 Urban Tribalwear show on his return to Sydney from a Crafts Board supported residency in New York, where he had been influenced by the inter-racial gay scene he encountered there. McDiarmid designed the poster (Figure 7) for this, and all of Tully's exhibitions. The support from the organised craft movement enabled Tully to simultaneously frame his work in terms of craft, community arts, fashion and gay cultural activism.

Tully had by 1980 exhibited in four one-person shows, including Passion for Plastics at, Ace Bourke's, Ace's Art Shop, in Edgecliff, Sydney (1976) and Craft's Paraphernalia Gallery, then in Collins Street, Melbourne (1977); Living Plastics (1977) and Peter Tully New Work (1978) had both been shown at Hogarth Galleries, Sydney. 


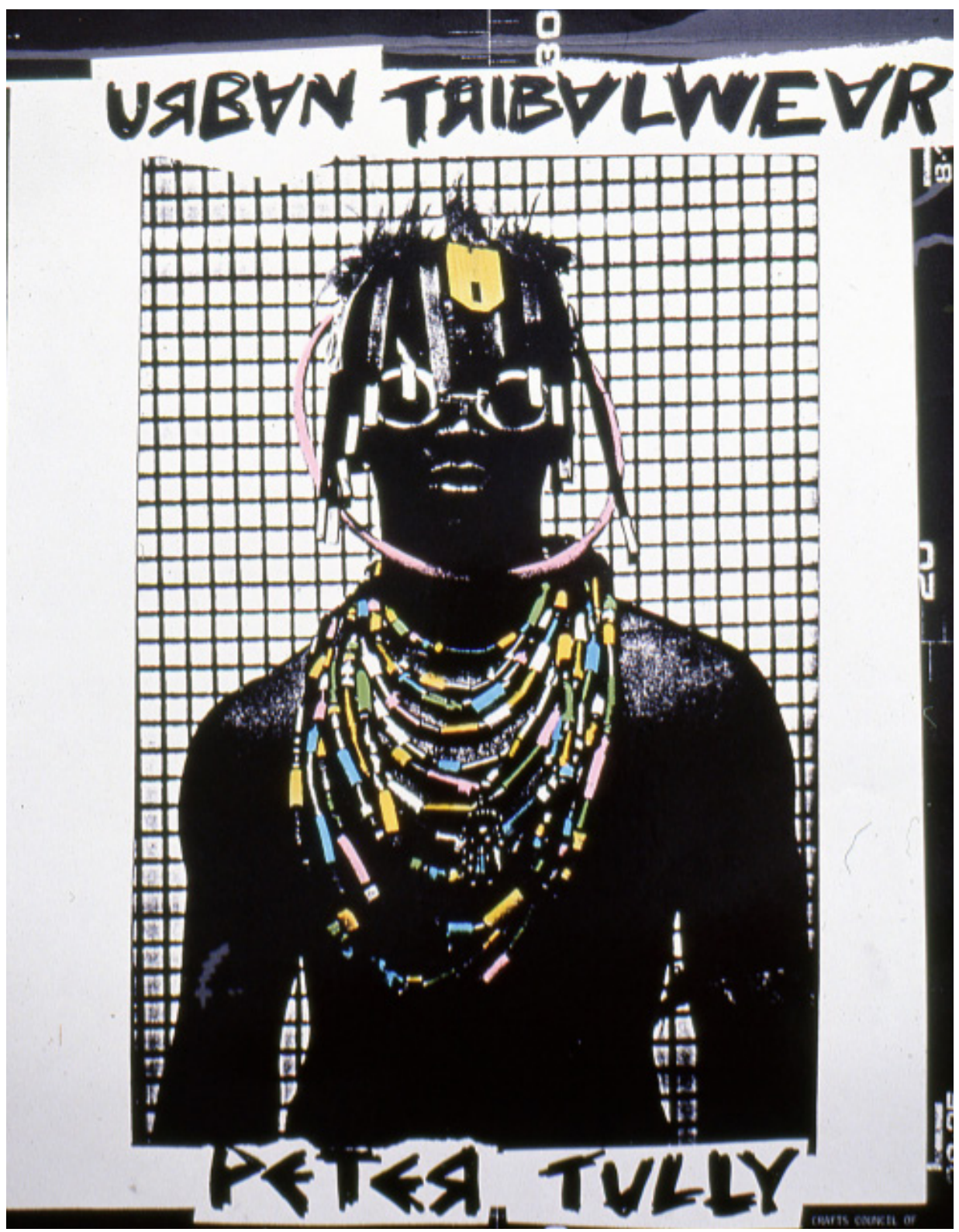

Figure 7. David McDiarmid, Peter Tully Urban Tribalwear poster, 1980.

Source: David McDiarmid.

All of these shows drew audiences who became devotees of Tully's 'outrageous' adornments (Eaton, 1985). His work after 1980 included a hybrid, sculptural form of fashionable adornment. Pieces such as the Ceremonial Coat for the Grand Diva of the Paradise Garage (1980) in the collection of the National Gallery of Australia, Canberra, and the New age business suit, in the Powerhouse Museum, Sydney, collection, are examples of Tully's performative fashion/craft 
practice, necessitating revised category definitions, which are still in play. Like the Tojo Tunic worn by Tully (Figure 8) they were often associated with dance party culture and his role from 1982 as artistic director of Sydney Gay and Lesbian Mardi Gras.

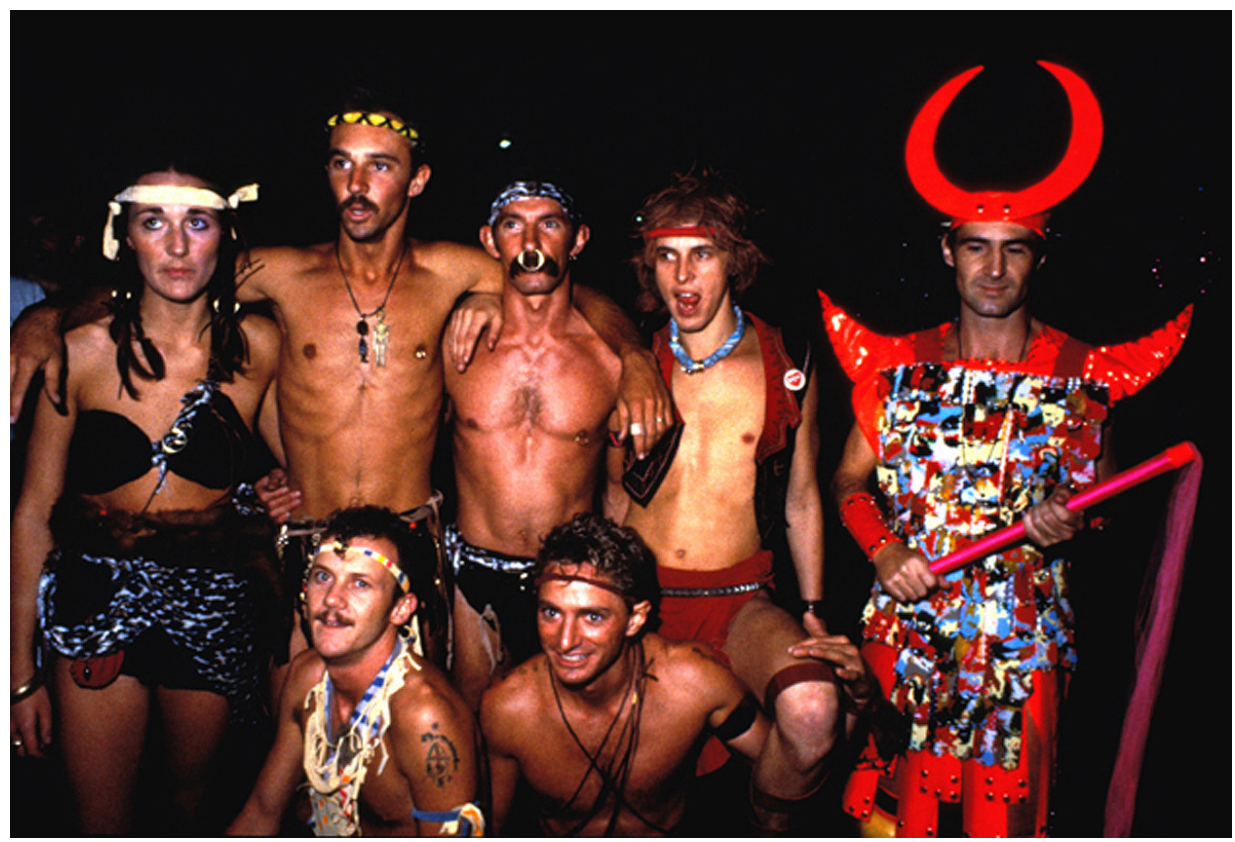

Figure 8. Peter Tully (right), and friends, at Sydney Gay and Lesbian Mardi Gras, 1981. Tully is wearing Tojo Tunic.

Source: William Yang.

Tully was included in Crafts Board-supported group shows such as Ten Australian Jewellers (1977), travelling through South East Asia and the Pacific, and Objects to Human Scale (1979-80) travelling to Japan, the Philippines and Hong Kong. The Crafts Board of the Australia Council awarded him grants in 1979, 1982 and 1984. Tully's jewellery was sold in a fashion context through Flamingo Park and he made specially conceived pieces to go with Jackson's outfits, for example the Artist series he created for Jackson's evening dresses in the 1975 Flamingo Follies parade, at Bondi Pavilion. His necklaces, especially, were must-have accessories for hip young people (women and men) from Sydney, Melbourne and beyond.

Chai was more in the group picture in the late 1960s and early 1970s when he and Tully were making outfits for camp arts balls and parties and perfecting a form of independent-minded, queer-conscious, masculine clothing and deportment in Melbourne - Chai's airmen's suits were legendary (Craft, 2010). He was showing Kee's and Jackson's clothes in his Melbourne Chai parades in the late 1970s. After Sydney temporarily became the epicentre of Australian fashionability, from the mid 1970s, the creative dialogue within this group would become more of a Sydney thing and in 1983 Chai decided to also move north and concentrate 
on making party outfits for the vibrant gay dance-party scene in Sydney. Based in the Strand Arcade, he shared group Arcade fashion parades with Flamingo Park. There are, however, traceable aesthetic links between members of the group throughout the 1970s and 1980s. A multi-directional discussion went on, sometimes intermittently, between the early 1970s and the end of the 1980s, in letters, conversations and in shared public display (parades, exhibitions, shops, museums and galleries), between McDiarmid, Jackson, Tully, Kee and Chai about what was fabulous and where it could be seen, experienced and appropriated into life or work.

\section{Craft political discourse}

Feminist retrieval of traditional women's crafts in the 1970s had the ideological dimension of re-evaluating the historical work of women, making it newly radical, instead of anachronistic. A related aesthetic valuing of the crafted, the decorative and the allegorical was seen in the hand-painted fabrics of McDiarmid, discussed above. Craft discourse and fashionable gay male iconography also gave a context to McDiarmid's gay activist art. McDiarmid saw the retrieval of craft techniques as a political matter; re-valuing work born of different, less powerful subjectivities. His artist statement for a February 1982 exhibition at the Crafts Council of Australia Gallery in Sydney, claimed:

I'm interested in popular culture. My work is in the intersection between folk art, women's art (needlepoint, patchwork quilts) and contemporary materials, I use loud cheap and vulgar plastics to make 'pretty Pictures'. (1982, n.p.)

For this show, The Australian Experience - Elements of Change, McDiarmid, then resident in New York, exhibited his Man Quilt (1978) now in the NGV. Using traditional quilting patterns and techniques, the work evokes a public/private homosocial world. The patchwork wall-hanging is meticulously hand-stitched, in the 'abutted and over-stitched', 'English' method of patchwork quilting, using coloured plastic hobby thread. McDiarmid's design, in traditional 'star-block' and 'four-patch' quilting patterns, uses repeat images of handsome 'clones', the then dominant gay male sartorial and grooming stereotype. Fragments of the Pink Personals columns from the Advocate, a San Francisco gay paper, and fragments of red and black bandannas, signalling sexual-practice codes, make up the rest of the patchwork patterns. McDiarmid saw himself primarily as an artist but, as he says above, he was happy to place himself in the spaces between craft and art. He worked on various specifically fashion projects between the mid 1970s and the early 1990s, including, but not limited to, the collaborations with Jackson discussed above (Gray, 2010).

Both the craft revival and the community arts movement were linked to the rejection of dominant Western values relating to class, gender, race and sexuality. Work such as Man Quilt, and the community arts discourse which informed both Tully and McDiarmid's tenures as artistic directors of the Sydney 
Gay and Lesbian Mardi Gras, coalesced with New Left counter-cultural ideas about identity and subjectivity which had also influenced the craft revival. Tully was Mardi Gras workshop artist and artistic director from 1982 until 1986 and McDiarmid from 1988 to 1990.

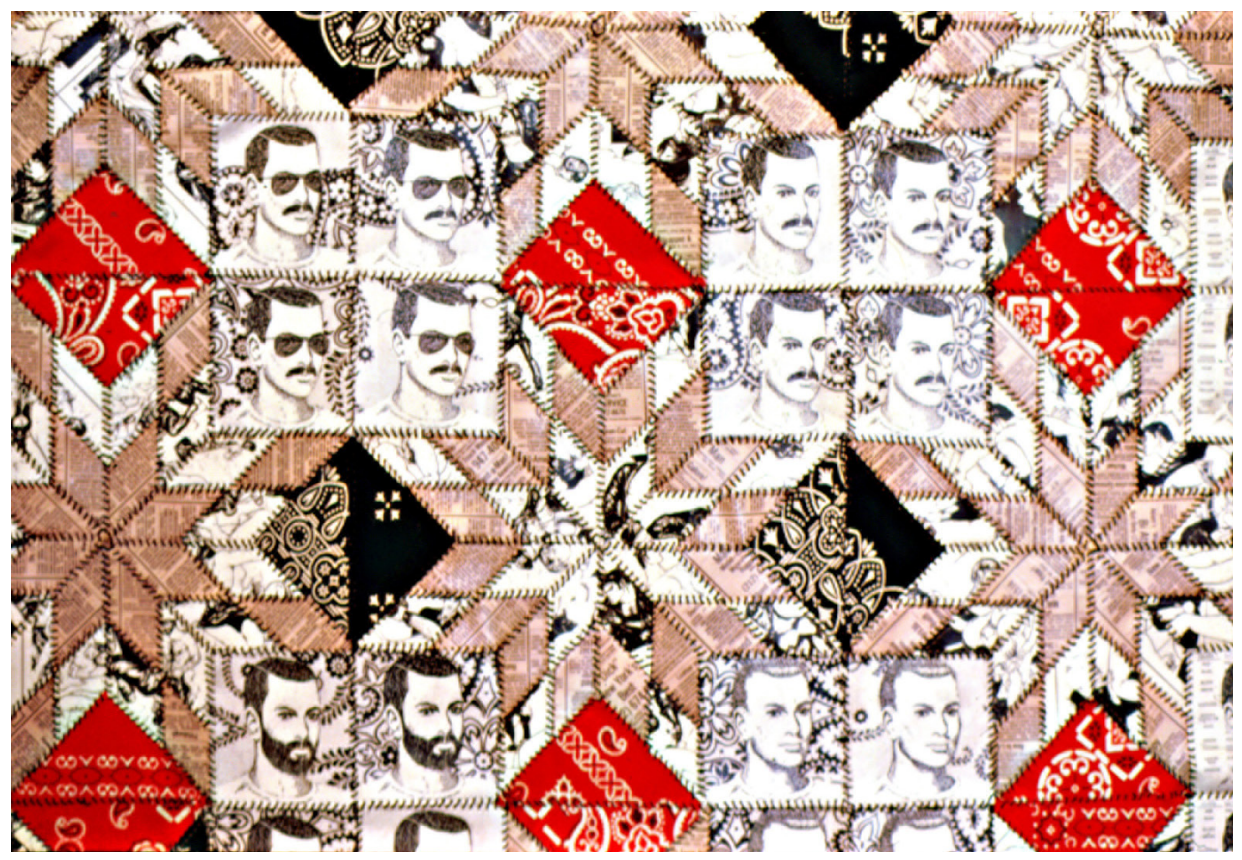

Figure 9. David McDiarmid, Man Quilt (detail), 1978. Hand-stitched patchwork wallhanging, vinyl, plastic, cotton, paper, chrome $(145.8 \times 120 \mathrm{~cm})$.

Source: David McDiarmid.

\section{Collecting and exhibiting}

Collecting and exhibiting policies in some Australian museums and galleries in the 1970s and 1980s embraced a looser approach to classification and ranking of art forms, and included craft and decorative arts. This energised the exhibiting and collecting of the work of this group. The directions taken at the ANG and the re-opened Museum of Applied Arts and Sciences in Sydney (as the Powerhouse Museum in 1988) would be important. In Canberra, James Mollison, later the national gallery's first director, was, as exhibitions officer in the Department of Prime Minister and Cabinet, the first full-time professional force behind the development of a collecting philosophy for Australia's nascent national gallery, as it moved towards its opening in 1982.

Born and raised in Victoria, Mollison traces the origins of his visual sensibility, in part, to the NGV collection. He said in a 2003 interview: 
I grew up in Melbourne. The National Gallery of Victoria contains marvellous prints and drawings, decorative arts and photography at least equal in quality to the collection of paintings. It never occurred to me that some things were better than others because of their category. $(2003$, p. 23)

John McPhee, founding curator of Australian decorative arts at the ANG, and Robyn Healy, who became curator of fashion and theatre arts there, both agree that there was an unusually open and interdisciplinary atmosphere surrounding the ANG's collecting, researching and exhibiting in its early years. 'What was done in Canberra was quite deliberate', says McPhee (2010). The specifically national role of the gallery was seen as being, not simply about canons of painting and sculpture, but also about providing a contemporary national picture; collecting objects and research material which could stimulate creativity and production in a variety of Australian visual practices. As Healy says of the acquisition of the significant Julian Robinson (fashion and textile) collection in 1976: 'It was seen as important, not just in terms of exhibiting, but also as a research collection' (2010). McPhee was among the earliest curators to recognise and interpret the decorative and symbolic languages employed by this group of practitioners and he made early acquisitions of their work. One of the earliest was the 1980 commission, for the ANG, of Tully's Ceremonial Coat for the Grand Diva of the Paradise Garage. This vibrant wearable object fabricated from DayGlo-coloured plastics, vinyls, fun-fur and found objects, was inspired by Tully's and McDiarmid's experience on the dance floor of the New York underground, black and Hispanic dance club, Paradise Garage (Gray, $2007,2011)$. There were no exact precedents for the ANG's interdisciplinary collecting of Australian decorative arts and unclassifiables such as the grand diva's coat.

Even things like writing of labels took endless hours of discussion, there were no real published catalogues of the [objects] we were collecting. The V\&A for example would have regarded what we were collecting as beneath them. (McPhee, 2010)

Interdisciplinary categorisations of objects thus made openings for the collecting and exhibiting of a variety of Australian creative practice. As the Powerhouse Museum moved towards its 1988 re-opening, in new premises, a collection initiative to make up for years of neglect of modernist and postmodernist craft and decorative arts collecting was underway, assisted by funds from the Crafts Board of the Australia Council and MOJO MDA (Varley, 1988). This was accelerated by the planned exhibition A Free Hand: Forty years of Australian Crafts 1940s-1980s, which aimed to include contemporary work from the burgeoning interdisciplinary crafts scene. The catalogue for this exhibition noted that: 'As the boundaries between all art forms are blurred, the boundaries of craft practice have extended' (Cochrane, 1989). Tully, Jackson and McDiarmid were collected and exhibited at the Powerhouse under this rubric. 


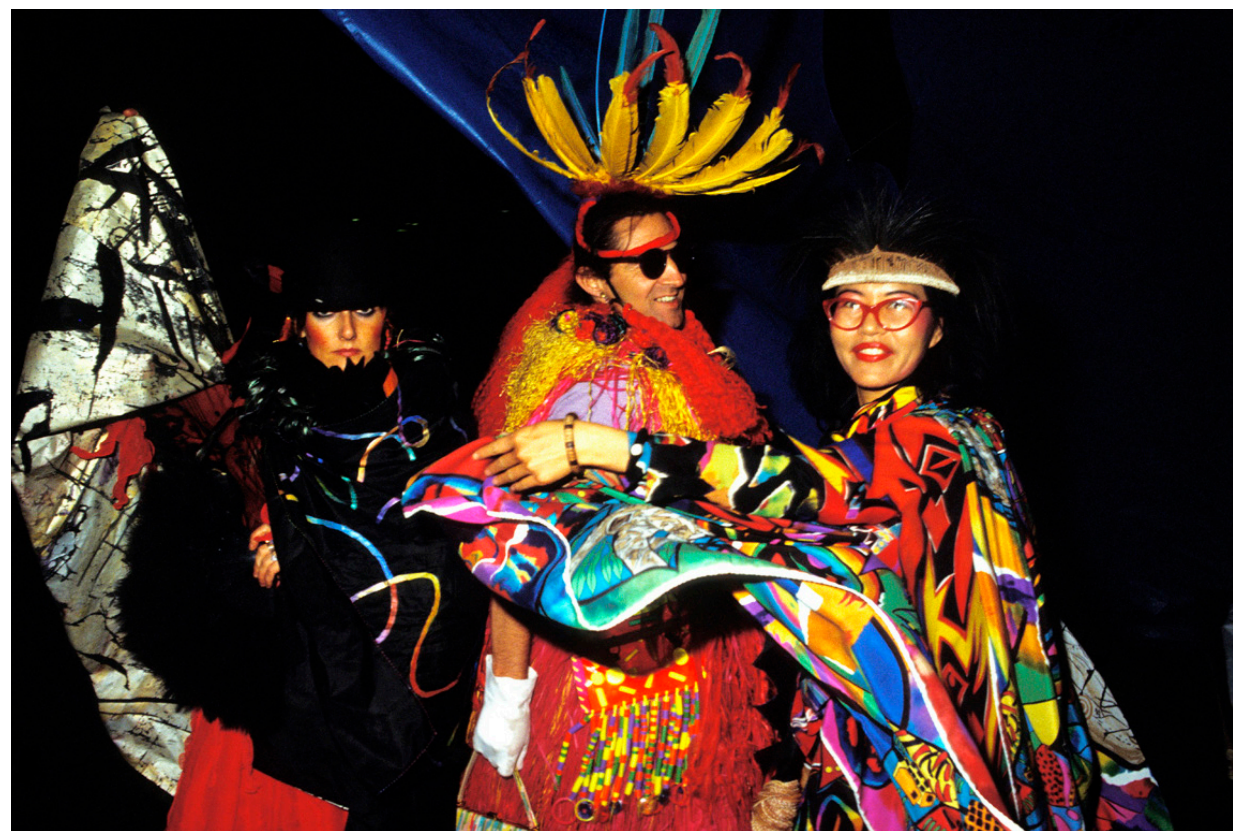

Figure 10. Linda Jackson (left), Peter Tully (centre) and Jenny Kee (right) at the opening of the Australian National Gallery, Canberra, 1982.

Source: William Yang.

\section{Fashion, art, design, craft: Interdisciplinary exhibitions}

I was interested in the really hip, the contemporary people who were working in dress, as just one of the ways they were working, or it might have been the main way they were working. (Jane de Teliga, 2011)

A special cultural framing for the critical interpretation and popular reception of the work of this group of practitioners was also provided by key inter-disciplinary fashion exhibitions curated by Jane de Teliga in the 1980s. The first of these was Art Clothes at the Art Gallery of New South Wales (AGNSW) (1980-81). It included Jackson, Kee, Tully, McDiarmid and 12 others whose practice covered jewellery, various approaches to clothing and personal adornment, and handpainted and printed textiles. This was followed by Art Knits, also at the AGNSW, in 1988. The contemporary influence of these two exhibitions can hardly be overestimated. They popularised the idea of inter-disciplinary visual creativity for the body. The easily assimilated 'art-clothes' language was communicated on a national level through the canvassing of work for Art Knits from all over Australia and through the national publicity generated by the projects.

The popular success of de Teliga's first two Australian fashion exhibitions was followed by the larger and more ambitious Australian Fashion: The Contemporary Art of 1989-90, which she proposed to, and curated for, the 
Powerhouse Museum. This widely applauded exhibition was shown at the Twentieth Century Gallery of the Victoria and Albert Museum in London, Marimura Art Museum in Tokyo and the Shinsegae department store in Seoul, as well as at the Powerhouse Museum in Sydney. A handsome catalogue, with photography by Monty Coles, was produced by Vogue Australia, which partnered with the exhibition to celebrate its 30th anniversary. The financing of Art Knits and Australian Fashion: The Contemporary Art by state and national Bicentennial funds invited a resonance with national iconography and cultural nationalism, as well as with craft and other contemporary discourses (feminism, gay liberation), and helped make the three exhibitions a cultural force.

Small 'project' exhibitions, organised by McPhee and Healy at the ANG, also placed the work of these practitioners in an interdisciplinary context in which categories of craft, art and fashion resonated. Linda Jackson and Jenny Kee: Flamingo Park and Bush Couture (1985) showed selected examples of Jackson's and Kee's work, including fabrics painted by McDiarmid, and jewellery by Tully, most of which had been acquired by the ANG in the early 1980s. Plastic, Rubber and Leather: Alternative Dress and Decoration (1986), also developed by McPhee and Healy, and including work by Tully, Jackson and McDiarmid, noted the blurring of 'distinctions between art, craft and fashion' and saw the roles of artist, craftsperson and fashion designer becoming more 'interchangeable' (McPhee, 1986).

\section{Conclusion}

This essay traces some of the ways in which friendships, formed around shared aesthetic sensibilities, can influence both the nature of those friendships themselves, and the creative outputs of the respective individuals. I have shown how five young Australians - Jackson, Kee, McDiarmid, Tully and Chai shared one-to-one and inter-connected group friendships, a visual enthusiasm for early twentieth-century decorative modernisms, and ideas about modes of making which they brought to bear on their creative work in art and fashion. They, variously, lived together, worked together, presented their work together and shared business relationships. They were all widely travelled, with an eclectic approach to absorbing influences from the world's cultures. Radical and counter-cultural ideas, including in the case of Tully and McDiarmid a specific agenda for social change, provided a background atmosphere to the friendships, and creative practice, of all five, as they sought to create lives and work that were vibrant, irreverent and exciting. The reception of their work was influenced by the aesthetic sensibility of a number of influential curators, namely Mollison, McPhee, de Teliga, and Healy, and by related discourses around interdisciplinarity in visual culture. These interdisciplinary discourses brought craft, design, art, fashion and politics into new relational configurations, providing momentum for both the group's output and for their popular and institutional reception. 
Sally Gray is an independent curator. She recently co-curated David McDiarmid a Short History of Facial Hair at the Fashion Space Gallery, London College of Fashion (2011) and is guest curator of the (2014-15) David McDiarmid retrospective at the NGV. She wrote her PhD (UNSW 2006) on the life and work of David McDiarmid. She is an Australian Postdoctoral Fellow (2010-12) at the University of NSW, writing a book on Sydney fashionability in the 1970 s and 1980s.

\section{Bibliography}

Barden, Robin, 1981, 'Clarence Chai', Virgin Press, Oct./Nov., pp. 15, 27

Barden, Robin, 1983, 'Fashion '83', Tension 1, p. 18

Best, Stephen and Kellner, Douglas, 1997, The Postmodern Turn, New York and London: The Guildford Press

Bourriaud, Nicolas, 2002, Relational Aesthetics, Dijon: Les Presses du Reel

Chai, Clarence, 2010, 2011, interviews with writer, Sydney, 21August; 5 January

Cochrane, Grace, 1989, A Free Hand: Forty Years of Australian Crafts 1940s-1980s, Sydney: Powerhouse Museum

Cochrane, Grace, 1993, 'Said and Done? Writing a History of the Crafts Movement'. In: P. Timms ed., Writings on Craft: The Nature of the Beast, Melbourne: Craft Victoria, pp. 6-11

Craft, Paul, 2010, interview with writer, Sydney, 14 January

Crafts Board, Australian Council for the Arts, 1975, Submission to Senate Standing Committee on Education Science and the Arts Vol. 3, Crafts Board, August, [Document access: Australia Council Library Sub353.770994AUS]

Damase, Jacques, 1972, Sonia Delaunay Rhythms and Colours, London: Thames and Hudson, (1971 Hermann, Paris)

de Teliga, Jane, 2011, interview with writer, Sydney, 12 January

Eaton, Matthew, 1985, 'Jewellery to be "outrageous" in', Brisbane Courier Mail, 14 January, (n.p.)

Gray, Sally, 1999, 'Celebrating Hybridity: David McDiarmid's Textile Designs', Art and Australia, vol. 37, pp. 96-101

Gray, Sally, 2007, 'Reinterpreting a Textile Tradition - David McDiarmid's Klub Kwilt', Textile History, The Journal of the Pasold Research Fund, vol. 38, no. 2, November, pp. 198-210 
Gray, Sally, 2010, 'Crafting Hip and Cool: David McDiarmid's Handcrafted Lamb Suede Dancefloor Outfits, 1980-1989', The Journal of Modern Craft, vol. 3, no. 1, March, pp. 37-54

Gray, Sally, 2011, 'David McDiarmid, Peter Tully and the Ecstatic Space of the Paradise Garage'. In: Glenn Adamson and Jane Pavitt eds, Postmodernism Style and Subversion 1970-1990, London: V\&A Publications

Healy, Robyn, 2010, interview with writer, Melbourne, 5 August

Jackson, Linda, 1987, Linda Jackson: The Art of Fashion, Sydney: Fontana Books

Jackson, Linda, 2009; 2011, interviews with writer, Sydney, 6 May; 2 March

Jocic, Laura, 2012, Linda Jackson Bush Couture, Melbourne: National Gallery of Victoria

Kee, Jenny, 2006, A Big Life: Jenny Kee, Melbourne: Lantern Books

Kee, Jenny, 2011, interview with writer, Sydney, 10 February

Leong, Roger and Somerville, Katie, 2010, 'Beyond the Boundaries: Australian Fashion from the 1960s to the 1980s'. In: Bonnie English and Liliana Pomazan eds, Australian Fashion Unstitched: The Last 60 Years, Melbourne: Cambridge University Press

McDiarmid, David, 1982, Artist's statement, The Australian Experience Elements of Change, 22 February - 31 March, exhibition catalogue. Sydney: Crafts Council of Australia

McPhee, John, 1985, Linda Jackson and Jenny Kee Flamingo Park and Bush Couture. Canberra: Australian National Gallery.

McPhee, John, 2010, interview with writer, Sydney, 19 April

Maynard, Margaret, 1999, 'The Red Centre: The Quest for "Authenticity" in Australian Dress', Fashion Theory, vol. 3, no. 2, pp. 175-96

Maynard, Margaret, 2001, Out of Line: Australian Women and Style, Sydney: University of New South Wales Press

Mehra, Annie, 1984, 'Clarence Chai Takes Oz in Style', Pacific: American Express Magazine, Oct-Dec. (n.p.)

Mollison James, 2003, in conversation with Anne Gray, in Pauline Green ed., Building the Collection, National Gallery of Australia and Thames and Hudson, pp. 23-31

Piaggi, Anna, 1977, 'Australian Graffiti' in 'Anna Piaggi's Box' Vogue Italia, December 
Pritchard, Jane, 2010, Diaghilev and the Golden Age of the Ballets Russes 1909-1929. London: V\&A Publishing

Spencer, Charles, 1973, Leon Bakst. London and New York: St Martins Press

Varley, Jane, 1988, 'The Recent Past', Craft Australia, no. 2, (n.p.)

Whitfield, Danielle, 2010, ‘Independent Australian Fashion'. In: Margaret Maynard ed., Encyclopedia of World Dressand Fashion, vol. 7 Australia, New Zealand and the Pacific Islands, Berg, Oxford and New York, pp. 168-73

Yang, William, 1984, Sydney Diary 1974-1984. Darlinghurst, NSW, James Fraser 
